\title{
Destinasyon Yönetimi Sürecinde Kongre ve Ziyaretçi Büroları: Antalya Kongre Bürosu Örneği
}

\author{
Öğr. Gör. Dr. Ali İNANIR \\ Burdur Mehmet Akif Ersoy Üniversitesi, Ağlasun Meslek Yüksekokulu \\ ainanir@mehmetakif.edu.tr \\ https://orcid.org/0000-0001-8647-3375
}

DOI: https://doi.org/10.37847/tdtad.1021953

Makale Gönderim Tarihi: 10.11.2021
Makale Türü: Araştırma Makalesi

Makale Kabul Tarihi: 03.01.2022

Özet

Amaç: Araştırmanın amacı destinasyon yönetimi sürecinde kongre ve ziyaretçi bürolarının genel etkinliğini ortaya koymaktır.

Yöntem: Araştırmanın yapısına uygun olarak nitel araştırma yöntemi kullanılmıştır. Verilerin toplanmasında yarı yapılandırılmış mülakat soruları yardımıyla, görüşme yönteminden yararlanılmıştır. Bu doğrultuda araştırmanın uygulama alanı olan Antalya Kongre Bürosunun yönetiminde yer alan ve profesyonel kongre organizatörlügü yapan, alanında uzman kişiler ile görüşmeler gerçekleştirilmiştir.

Bulgular: Elde edilen veriler içerik analizi ile analiz edildikten sonra Antalya Kongre Bürosunun tanıtım, pazarlama ve bilgilendirme konularda etkin olduğu fakat destinasyon yönetimi sürecinde; üye sayısı, finansal kaynak tahsisi, büro personeli sayısı, bürokrasi, kurumlar arası iletişim, amaç birliği oluşturma konularında problemlerle karşılaştığı ortaya çıkmıştır.

Tartışma: Destinasyonların etkin yönetiminin gerekliliğinin her geçen gün artmasına bağlı olarak, ortaya konulan araştırmaların aktörlere yol gösterici olabileceği düşünülmektedir.

Anahtar Kelimeler: Destinasyon Yönetimi, Nitel Araştırma, Kongre ve Ziyaretçi Büroları, Antalya.

\section{Congress and Visitor Bureaus in the Destination Management Process: The Case of Antalya}

\section{Abstract}

Purpose: The aim of the research is to reveal the general effectiveness of congress and visitor bureaus in the destination management process.

Design: Qualitative research method was used in accordance with the structure of the research. The interview method was used to collect the data with the help of semi-structured interview questions. Accordingly, interviews were held with professional congress organizers who are taking part in the management of Antalya Congress Bureau, which is the field of application of the research.

Findins: The obtained data were analyzed by content analysis method. In this regard Antalya Congress Bureau is effective in the promotion, marketing and information issues, but, it was revealed that faced problems in the destination management process of number of members, allocation of financial resources, number of office personnel, bureaucracy, communication between institutions, creating unity of purpose.

Discussion: Due to the increasing necessity of effective management of destinations day by day, it is thought that the researches put forward can guide the actors.

Key Words: Destination Management, Qualitative Research, Congress and Visitor Bureaus, Antalya. 


\section{Giriş}

Destinasyonlar, turizmin kırılgan yapısından dolayı yönetilmesi oldukça zor olan alanlardır. Aynı zamanda destinasyon yönetim sürecinde bir taraftan aktif olarak paydaşların sürekli işbirliği içinde olması zorunluluğu, diğer taraftan birçok paydaşın sürece dahil edilmesi gerekliliği destinasyonların yönetimini karmaşık hale getirmektedir. Yapı olarak destinasyon yönetimi turistler, turizme hizmet verenler ve yerel halk arasındaki koordinasyona bağlı, destinasyonların ekonomik ve kültürel kalkınmasını teşvik eden bir sistem olarak ortaya çıkmaktadır (Speakman ve Sharpley, 2012).

Turistik destinasyonlarda destinasyon yönetiminin sağlanması, destinasyon yönetim örgütleri vasıtası ile gerçekleşmektedir. Destinasyon yönetim örgütleri, uzun vadede destinasyon rekabetçiliğinin sağlanması ve sürdürülebilmesi adına kurulan yapılardır (Ritchie ve Crouch, 2003). Ulusal, bölgesel ve yerel boyutta örgütlenen destinasyon yönetim örgütlerinin içinde yerel boyutta destinasyonların yönetiminden ve pazarlanmasından sorumlu olan organizasyon kongre ve ziyaretçi bürolarıdır. Kongre ve ziyaretçi büroları; ziyaretçiler ve toptancılar için destinasyonların daha çekici hale gelmesi adına destinasyonların imajını arttırma, ürün geliştirme, kongre alıcıları ile satıcılarının temsilciliğini yapma, ziyaretçilerin sorunlarını çözme, destinasyonların tanıtımını ve pazarlanmasını sağlama gibi görevleri de yerine getirmektedir. Bu duruma bağlı olarak genellikle kongre ve ziyaretçi bürolarının pazarlama yönü birçok araştırmacı (O'neill, 1998; Weber, 2001; Beldona, Morrison ve Anderson, 2003; He ve Love, 2005; Baytok, Soybalı ve Emir, 2010) tarafından ele alınmıştır.

Turizmin bir destinasyonda büyümesi ve gelişmesi amaçlı kurulan destinasyon yönetim örgütleri, destinasyonların yönetilmesinden sorumlu olan kuruluşlardır. Aynı zamanda yönetim faaliyetleri sırasında destinasyonların pazarlanma faaliyetlerini de sürdürmektedirler. Bu bağlamda kongre ve ziyaretçi büroları da yerel boyutta destinasyon yönetimi faaliyetlerini gerçekleştirirken, destinasyonların pazarlanmasını da sağlamaktadırlar (Ritchie ve Crouch, 2003). Buna rağmen kongre ve ziyaretçi bürolarının destinasyon yönetimi sürecindeki işleyişi doğrudan çok sinırlı araştırmacılar (Weber, 2001; Kovacevic, 2017) tarafından ele alındığı görülmüştür.

Kongre ve ziyaretçi büroları aynı zamanda destinasyon yönetimi sürecinde paydaşlar arasında işbirliği, iletişim eşgüdüm, liderlik ve şeffaflık konularında ilişkiler gerçekleştirmektedirler (Speakman ve Sharpley, 2012). Tüm bu nedenlere bağlı olarak araştırmanın amacı destinasyon yönetim sürecinde paydaşlar arası ilişkiler ve diğer boyutlarda kongre ve ziyaretçi bürolarının genel işleyişini tespit etmektir. Araştırmanın amacı doğrultusunda Türk turizminin başkenti olarak bilinen Antalya'da yer alan ve daha önce hiçbir araştırmada incelenmeyen Antalya Kongre Bürosu araştırmanın uygulama alanını oluşturmaktadır.

\section{Destinasyon Yönetimi}

Destinasyonlar ile ilgili turizm alan yazınında birden çok araştırma yapılmıştır. $\mathrm{Bu}$ araştırmalarda yazarlar tarafından farklı boyutlarda destinasyon olgusunun ele alındığ 1 görülmektedir. Nitekim $\mathrm{Hu}$ ve Ritchie (1993) yapmış oldukları araştırmalarında 
destinasyonları, çok boyutlu nitelikleri olan turizm olanaklarının ve hizmetlerinin bütünü olarak ifade etmişlerdir. Diğer bir tanımda ise Buhalis (2000) destinasyonları, turistlere bütünleşik bir deneyim sunan alanlar olarak ifade etmiştir. Turizmin bölgesel gelişimi ile ilgili araştırmasında model ortaya koyan Pearce (1992) destinasyonları, ziyaretçiler için sınırları ortaya konulmuş, bütünleşik ürün ve hizmetler sunan yerler olarak ifade etmiştir. Genel olarak bu tanımlarda destinasyonlar, altyapı ve üstyapı olanakları tamamlanmış, turistlere farklı alanlarda tamamlayıcı özellikleri olan yerler olarak ifade edilmiştir. Bu yerlerin Güripek ve Usta'ya (2018) göre kültürel ve ekonomik yapısının turizmin etkilerini bünyesinde barındırması gerektiği ifade edilmiştir. Aynı zamanda tanımlarda, destinasyonların arz yönü ortaya konulmuştur.

Diğer taraftan destinasyonların sürdürülebilir boyutta talep edilen yönünü ortaya koyan çalışmalarda araştırmacılar (Leiper, 1995; Penclaner ve Weiermaier, 2000; Tinsley ve Lynch, 2001) destinasyonları, bir dizi turistik ürün ve hizmetlerin yanında, doğal ve yapay çekicilikleri ile turistleri cezbeden özel olarak tasarlanmış coğrafi yerler olarak ifade etmişlerdir. Destinasyonların talep yönünü ortaya koyan diğer çalışmada ise destinasyonlar, ziyaretçilerin zihinlerinde oluşan algısal bir yer olarak ifade edilmiştir (Kotler, Bowen ve Makens, 2006).

Destinasyonlarda sürdürülebilirlik ile rekabetin sağlanması adına destinasyonların yönetilmesinde destinasyon yönetim örgütleri aktif rol oynamaktadır. Dünya Turizm Örgütünün yapmış olduğu tanıma göre bir organizasyon olarak destinasyon yönetim örgütleri, destinasyonların yönetilmesinden ve pazarlanmasından sorumlu olan örgütler olarak ifade edilmiştir (World Tourism Organization, 2004).

Destinasyon yönetim örgütleri çeşitli yapılarda oluşturulmuştur. Ülkelerin ekonomik olarak gelişmişlik durumuna göre oluşan bu yapılar ile destinasyonlar yönetilmeye çalışılmaktadır. Poetschke (1995)'e göre kamu-özel sektör işbirliğine dayanan farklı türde turizm paydaşlarının yer aldığı destinasyon yönetim örgütleri modelinin, turizm destinasyonlarının etkin bir şekilde yönetilmesinde ağırlıklı olarak kullanıldığ1 görülmektedir. Farklı türde paydaşların yer aldığı kamu-özel sektör işbirliğine dayalı bu yapılarda paydaşlar arası ilişkilerde meşruiyet, katılım, açıklık eşitlik, şeffaflık, fikir birliği ve uyum gibi farklı unsurların etkili olduğu görülmektedir (Graham, Amos ve Plumptre, 2003).

Destinasyon yönetim örgütleri ulusal, bölgesel ve yerel düzeyde farklı şekillerde sinıflandırılan örgütlerdir (Presenza, Sheehan ve Ritchie, 2005). Bu sinıflandırmada yerel düzeyde destinasyonların yönetilmesinden sorumlu olan destinasyon yönetim örgütlerinin kongre ve ziyaretçi büroları olarak ifade edilmiştir (Borzyszkowski, 2014).

\section{Destinasyon Yönetimi Sürecinde Kongre ve Ziyaretçi Büroları}

Kongre ve ziyaretçi büroları, destinasyonların yönetilmesinde ve pazarlanmasında önemli yeri olan kuruluşlardır (Getz, Anderson ve Sheehan, 1998). Bu kuruluşlar destinasyonların yönetilmesi sürecinde pazarlama faaliyetlerini de gerçekleştirmektedirler. Nitekim bu süreçte kongre ve ziyaretçi büroları destinasyonlardaki tüm kaynaklar, kongre organizatörleri, etkinlik planlamacıları, 
bireyler ve gruplar üzerinde etkinliği olan kuruluşlar olarak ortaya çıkmaktadır (Bramwell ve Rawding, 1994).

Kongre ve ziyaretçi bürolarının destinasyon yönetim sürecinde bir takım rol ve sorumlulukları bulunmaktadır. Bu bağlamda ilk olarak kongre ve ziyaretçi büroları profesyonel toplantı organizatörleri, tur operatörleri, oteller ve bireysel ziyaretçiler arasında işbirliği, karşılıklı güven ve iletişim sağlamaktadır (Wang, 2011; Kovacevic, 2017). Bu durum toplantı amaçlı destinasyonların ziyaretçi talebini arttırmaktadır. İkinci olarak potansiyel ziyaretçilerin satın alma karar sürecini etkilemeye yönelik pazarlama bilgi sistemi hizmeti sağlamaktadır (Wober, 2003). Bu bilgi sistemi, ziyaretçilerin destinasyonla ilgili ortaya çıkan sorularına yanıt bulmasını ve onlarla iletişim kurulmasını kolaylaştırmaktadır (Morrison, Bruen ve Anderson, 1998). Üçüncü olarak özel sektör ile kamu sektörü arasında koordinasyon sağlamaktadır. Bu sayede otel, motel, tatil köyü, ziyaretçi büroları ile kamu kuruluşları arasında oluşan koordinasyon vasıtasıyla destinasyonların geliştirilmesi, yönetilmesi, pazarlanması, yerel politikaların oluşturulması ve ekonomik olarak kalkınmasına fayda sağlamaktadır (Gartrell, 1993; Bramwell ve Rawding, 1994; Morrison vd., 1998; Presenza vd., 2005). Son olarak da kongre ve ziyaretçi büroları destinasyonların planlanması ve destinasyonlarda ürün geliştirme sürecinde aktif rol oynamaktadır (Gartrell, 1994). Destinasyon planlaması sürecinde hedeflerin belirlenmesi ve daha çekici ve başarılı turistik destinasyonlar oluşturma adına stratejilerin oluşturulması görevini yerine getirmektedir ve ürün geliştirme sürecinde ise ziyaretçilerin satın alma veya kullanması için çekicilikler veya hizmetler ortaya koymaktadır.

Kongre ve ziyaretçi büroları faaliyetlerini gerçekleştirdiği süreçte bir takım problemler ile karşılaşabilmektedir. Bu süreçte karşılaştığı en önemli sorun kaynak tahsisi, finansman ve personel desteğidir. Nitekim kongre ve ziyaretçi bürolarının en önemli finansmanı üye aidatları ve sponsorluklardır. Bu etmenin yetersiz olduğu bölgelerde kongre ve ziyaretçi büroları yönetim ve pazarlama faaliyetlerini etkin bir şekilde yerine getirememektedir. Kongre ve ziyaretçi büroları, kongre faaliyetlerinin gerçekleşmesi sırasında şehirlerin altyapı ve üstyapı yetersizliğinden dolayı problemeler yaşayabilmektedir. Bu durum arz ve talep arasında dengesizliklerin ortaya çıkmasına neden olabilmektedir. Kongre ve ziyaretçi bürolarının paydaşlardan yeterli desteği alamaması durumu da faaliyetlerini olumsuz etkilemektedir. Nitekim yönetim faaliyetleri sırasında paydaşların sağlamış olduğu destek ve pazarlama faaliyetleri sırasında ortak etkinliklerin gerçekleşmesi aşamasında verilen destek, kongre ve ziyaretçi bürolarının etkinliğini doğrudan etkilemektedir (Getz vd., 1998; Baytok vd., 2010).

\section{Yöntem}

Araştırmada nitel araştırma yöntemi kullanılmıştır. Nitel araştırma, bir problemin çözümünü gerçekleştirmeye yönelik olarak veri toplamayı amaçlayan bununla birlikte daha önceden bilinen fakat bireylerin dikkatinden kaçmış problemlerin algılanmasına, probleme ilişkin doğal olguların derinlemesine gerçekçi bir yöntemle ele alınmasına dayanan bir yöntemdir (Seale, 1999; Baltacı, 2019). Aynı zamanda nitel araştırmalar, küçük örneklem grubu ile yönetilebilmektedir (Marshall, 1996). Diğer bir ifadeyle nitel 
araştırmalarda ele alınan konuyu deneyimlemiş çok küçük örneklem kitlesiyle, çok daha kapsamlı ve detaylı veriler elde edilebilir (Starks ve Trinidad, 2007). Bu araştırmada da gerek araştırılan konunun daha önce derinlemesine pek fazla ele alınmamış olması, gerekse araştırma için örneklem sayısının sınırlı olmasından dolayı nitel araştırma yöntemi kullanılmasına karar verilmiştir.

Nitel araştırmalarda verilerin toplanması sürecinde görüşme diğer bir adıyla mülakat (yapılandırılmamış, yapılandırılmış, yarı yapılandırılmış ve odak grup görüşmesi) gözlem (katılımcı, katılımcı olmayan ve gizil), doküman analizi diğer bir adıyla arşiv taraması gibi farklı yöntemler kullanılabilmektedir (Creswell, 2012; Creswell, 2016; Berg ve Lune, 2016). Bu araştırmada verilerin toplanmasında görüşme (mülakat) yönteminden yararlanılmıştır. Görüşmelerin gerçekleştirilebilmesi adına konu ile ilgili alan yazın derinlemesine taranarak ve uzman görüşü alınarak beş adet yarı yapılandırılmış görüşme sorusu ortaya konulmuştur. Bu sorular;

1. Antalya Kongre Bürosu'nun kuruluş amacı nedir? Antalya Kongre Bürosu'nun diğer uluslararası destinasyonlardaki benzer oluşumlardan ayrılan yönleri ve ortak noktaları nelerdir?

2. Destinasyon yönetimi sürecinde Antalya Kongre Bürosunun rol ve sorumlulukları nelerdir?

3. Destinasyon yönetim sürecinde Antalya Kongre Bürosunda yer alması gereken paydaşlar kimlerdir?

4. Paydaşların birbirleriyle ilişkilerinde etkili olan unsurlar nelerdir?

5. Destinasyon yönetim sürecinde Antalya Kongre Bürosunun karşılaştı̆̆ı sorunlar nelerdir? Bu sorunlar nasıl çözüme kavuşturulabilir?

Araştırmanın örneklemeni belirleme adına nitel araştırmalarda en sık kullanılan amaçlı örneklemeden yararlanılmıştır çünkü amaçlı örnekleme alanında uzman kişilere ulaşma sürecinde kolaylık sağlamaktadır. Bu bağlamda araştırma sürecinde ortaya konulan araştırma sorularına derinlemesine yanıt bulunabilmesi ve uzman kişilerin görüşlerinin alınabilmesi adına öncelikle Antalya Kongre Bürosunun yönetiminde yer alan ve profesyonel kongre organizatörlüğü yapan katılımcllardan randevu istenmiştir. Özellikle pandemi sürecinden dolayı katılımcıların bazıları yüz yüze görüşmeyi, bazıları da zoom veya benzer programlar üzerinden toplantı yapmayı, bir katılımcı da e-mail üzerinden verileri göndermeyi kabul etmişlerdir. Görüşme için randevu istenen 3 kişi da pandemi ve iş yoğunluğunu ileri sürerek görüşmeleri kabul etmemiştir. Bazı görüşme talebinde bulunulan kişilere de mail gönderilmiş fakat geri dönüş alınamamıştır. Bu sinırlılıklar çerçevesinde araştırma sürecinde dört adet katılımcı ile görüşülerek bulgular ortaya konulmuştur. Araştırmanın dört kişi ile sınırlandırılmasının sebebi bazı kişilerin görüşmeleri kabul etmemesine rağmen elde edilen verilerde doyuma ulaşılması ve ilgili katılımcıların araştırma konusunda uzman, farklı özelliklere sahip kişilerden oluşmasıdır. Aynı zamanda alan yazın incelendiğinde nitel araştırma konusunda farklı araştırma teknikleri kullanılarak az sayıda katılımcılar ile kapsamlı çalışmaların (Yirik, Seyitoğlu ve Çakar, 2016; Çakar, Kalbaska, İnanır ve Şahin Ören, 2018) ortaya konulduğu tespit edilmiştir. Araştırma 12.01.2020 ile 04.04.2021 tarihleri arasında gerçekleştirilmiştir. 
Nitel araştırmalarda verilerin geçerliliği ve güvenilirliği de önemli bir husus olarak ortaya çıkmaktadır. Nitekim araştırma sürecinde katılımcıların ve meslektaşların teyidinin alınması, araştırmacının araştırma alanına yakın olması, doğrudan alıntıların verilerin sunumunda kullanılması ve veri analizinde başka araştırmacının kullanılması gibi koşullar yerine getirildiğinden dolayı bu araştırmanın geçerliliği ve güvenilirliğ kısmen sağlanmıştır, denilebilir.

\section{Bulgular}

Araştırma sürecinde ilk olarak katılımcılar K1, K2 ve K3, K4 şeklinde kodlanmıştır. Daha sonra katılımcılar ile ilgili demografik bilgiler Tablo 1'de sunulmuştur.

Tablo 1: Katılımcılara Ait Demografik Veriler

\begin{tabular}{|l|l|l|l|l|l|}
\hline Katılımc1 & Yaş & Cinsiyet & $\begin{array}{l}\text { Eğitim } \\
\text { Durumu }\end{array}$ & Meslek & $\begin{array}{l}\text { Kurumdaki } \\
\text { pozisyonu }\end{array}$ \\
\hline K1 & 50 & Erkek & Doktora & Akademisyen & $\begin{array}{l}\text { Yönetim } \\
\text { Kurulu } \\
\text { Üyesi }\end{array}$ \\
\hline K2 & 42 & Kadın & $\begin{array}{l}\text { Yüksek } \\
\text { lisans }\end{array}$ & Otel Yöneticisi & Yönetici \\
\hline K3 & 49 & Kadın & Lise & Otel Yöneticisi & Üye \\
\hline K4 & 37 & Kadın & Lisans & $\begin{array}{l}\text { Profesyonel } \\
\text { Kongre } \\
\text { Organizatörü }\end{array}$ & Üye \\
\hline
\end{tabular}

Tablo 1 incelendiğinde katılımcıların yaş ortalamasının 45 olduğu ve orta yaş grubunda olduğu görülmektedir. Katılımcıların çoğunluğu kadındır ve eğitim durumları ağırlıklı olarak lisans ve lisansüstü şeklindedir. Katılımcıların meslek grupları incelendiğinde ise akademisyen (Profesör), turizm sektöründe yönetici ve profesyonel kongre organizatörlüğü gibi etkin meslek gruplarında çalıştığı görülmektedir. Katılımcların kurumdaki pozisyonları ele alındığında ise yöneticilik, yönetim kurulu üyeliği ve kurum üyeliği gibi farklı kategorilerde görevli olan kişiler olduğu saptanmıştır.

Nitel araştırma yönteminin tercih edildiği araştırma da veriler içerik analizi ile analize tabi tutulmuştur. Bu süreç metinsel veya sembolik olarak içerik akışının sistematik bir biçime indirgenmesini kapsamaktadır (Gray ve Densten, 1998). Bu kapsamda katılımcılar ile görüşmeler gerçekleştirildikten sonra elde edilen veriler transkriptlere aktarılmış ve daha sonra gerçekleştirilen içerik analiziyle kategori ve alt kategoriler ortaya konulmuştur. Bu durum Tablo 2'de ifade edilmiştir.

Tablo 2: Kategori ve Alt Kategoriler

\begin{tabular}{|l|l|}
\hline Kategori & Alt Kategori \\
\hline Rol ve Sorumluluk & $\begin{array}{l}\text { Satış ve Pazarlama } \\
\text { Tanıtım } \\
\text { Enformasyon }\end{array}$ \\
\hline Destinasyon Yönetimi & $\begin{array}{l}\text { Paydaşlar } \\
\text { Paydaşlar Arası İlişkiler }\end{array}$ \\
\hline Karşılaşılan Sorunlar & Üye Sayısı \\
\hline
\end{tabular}




\begin{tabular}{|l|l|}
\hline & Finansal Kaynak Tahsisi \\
& Personel Sayısı \\
& Bürokrasi \\
& Kurumlar Arası İletişim \\
& Ortak Karar Alma \\
& Amaç Birliği \\
\hline
\end{tabular}

Tablo 2 incelendiğinde elde edilen verilerin analizinden sonra üç adet kategori ve on iki adet alt kategori ortaya çıkmıştır. Bu doğrultuda rol ve sorumluluklar kategorisi altında satış ve pazarlama, tanıtım ve enformasyon; destinasyon yönetimi kategorisi altında paydaşlar ve paydaşlar arası ilişkiler; karşılaşılan sorunlar kategorisi altında üye sayısı, finansal kaynak tahsisi, personel sayısı, bürokrasi, kurumlar arası iletişim, ortak karar alma ve amaç birliği gibi alt kategoriler ortaya çıkmıştır.

Kongre ve ziyaretçi büroları faaliyetlerini devam ettirdiği süreçte bir tanım rol ve sorumlulukları yerine getirme amaçlı misyonlar üstlenmektedirler. Nitekim bu doğrultuda destinasyonların yönetimi (Kovacevic, 2017) ve pazarlanması (Beldona vd., 2003), reklam ve tanitım (Gartrell, 1994), bilgilendirme (Weber, 2001) gibi rol ve sorumlulukları üstlenmişlerdir. Alan yazın bilgileri destekler nitelikte Antalya Kongre Bürosu da destinasyonların kongre turizmi amaçlı satışının ve pazarlamasının gerçekleştirilmesi, destinasyonların tanıtılması ve kongre turizmi planlamacılarına, paydaşlarına ve kongre turizmi katılımcılarına bilgi verilmesi görevlerini kar amacı gütmeden yerine getirme amaçlı bir takım rol ve sorumluluklar üstlenmişlerdir. Bununla birlikte ülkemizde diğer kongre büroları ile karşılaştırıldıklarında İstanbul Kongre ve Ziyaretçi Bürosundan sonra en aktif çalışan kurum olduğu görülmektedir. İstanbul Kongre ve Ziyaretçi Bürosunun daha etkin olmasının sebebi olarak İstanbul'un gerek alt yapı ve üst yapı olanakları gerekse kongre turizmi sürecinde katılımcllara sunabileceği kaynakların fazla olması olduğu tespit edilmiştir.

"İstanbul ve Antalya Kongre ve Ziyaretçi Büroları çıkardıkları yayınlarla (meeting planner, takvimler, ile ait yöresel mutfak, bitki türleri vs) yurtiçi ve yurtdışında tanıtım yapmakta, toplumdaki bireylere etkinlik turizminin ekonomik, sosyal ve kültürel düzeylerdeki önemi anlatmakta, satış ve pazarlama alanında çalışanlara teklif verme, tanıtım, etkinliklere ev sahipliği konusunda bilgiler aktarmaktadır. Iller bazında en aktif çalışan İstanbul, ardında da Antalya Kongre ve Ziyaretçi Bürosudur." (K1).

"Antalya Kongre Bürosu yurtiçinde ve yurtdışından etkinlik düzenlemek isteyenler için ilk ve en çok tercih edilen temas noktasıdır. Kar amacı gütmeyen ve Antalya ilinin ve ülkemizin dünya etkinlik pazarından daha fazla pay almasını sağlamaya gayret etmektedir. " (K2)

"İstanbul'da her türlü organizasyon yapılabiliyor, aktiviteler daha fazla çok daha fazla hizmet alabilme imkânları var. Deniz, vapur, tarihi yerler, otel kapasiteleri çok fazla, şehir otelleri olması şehrin gezilecek görülecek çok fazla değeri var." (K3).

"Pazarlama faaliyeti de çok farklı aslında. Buraya amaç ile gelen, İstanbul'a gelen arasında çok fark var." (K4).

Turistik destinasyonların yönetilmesi aşamasında paydaşların sınıflandırılması ve optimum seviyede paydaşın belirlenmesi önemli bir unsur olarak ortaya çıkmaktadır. 
Konu ile ilgili araştırma yapan Murphy ve Murphy (2004) yaptıkları araştırmalarında destinasyon yönetim sürecinde paydaşların kimler olduğu ve optimum seviyede sürece ne kadar paydaşın dahil edilmesi gerektiğinin belirlenmesi gerektiğini ifade etmişlerdir. $\mathrm{Bu}$ durumdan yola çıkarak yerel boyutta destinasyonların yönetilmesinden sorumlu olan kongre ve ziyaretçi bürolarında destinasyon yönetimi sürecinde yer alması gereken paydaşlarının belirlenmesi de önemli bir unsur olarak görülmektedir. Bu bağlamada araştırmanın gerçekleştirildiği Antalya Kongre Bürosu'nda destinasyon yönetimi sürecinde yer alması gereken paydaşlar ile ilgili katılımcıların vermiş olduğu cevaplara bağlı olarak Tablo 3 ortaya konulmuştur.

Tablo 3: Destinasyon Yönetim Sürecinde Yer Alması Gereken Paydaşlar.

\begin{tabular}{|l|c|}
\hline Paydaşlar & Katılımcı Sayıs \\
\hline Profesyonel Kongre Organizatörleri & 4 \\
\hline Oteller & 4 \\
\hline Kongre Merkezleri & 3 \\
\hline Üniversiteler & 3 \\
\hline Antalya Hava Limanı & 3 \\
\hline $\begin{array}{l}\text { Sivil Toplum Kuruluşları (AKTOB, } \\
\text { TÜROFED, TÜRSAB, TÜROB) }\end{array}$ & 3 \\
\hline Belediyeler & 2 \\
\hline $\begin{array}{l}\text { Antalya Kongre Bürosunun Yönetim Kurulu } \\
\text { Üyeleri }\end{array}$ & 1 \\
\hline Antalya Kongre Bürosunun Ofis Personeli & 1 \\
\hline Acenteler ve Tur Operatörleri & 1 \\
\hline Bankalar ve Sigorta Acenteleri & 1 \\
\hline Tanitım Ajansı & 1 \\
\hline Valilik & 1 \\
\hline
\end{tabular}

Tablo 3 incelendiğinde yukarıda ifade edilen paydaşların bir kısmı destinasyon yönetiminde Antalya Kongre Bürosunda yer almaktadır bununla birlikte katılımcıların tamamı destinasyon yönetim sürecinde yer alması gereken paydaşlar olarak profesyonel kongre organizatörleri ve otelleri ifade etmişlerdir. Katılımcıların \% 75'i kongre merkezleri, üniversiteler, Antalya Hava Limanı ve AKTOB (Akdeniz Turistik Otelciler Birliği) , TÜROFED (Türkiye Otelciler Federasyonu), TÜRSAB (Türkiye Seyahat Acentecileri Birliği), TÜROB (Türkiye Otelciler Birliği) gibi sivil toplum kuruluşlarını; Katılımcıların \% 50'si belediyeleri; katılımcların sadece \% 25'i ise Antalya Kongre Bürosunun yönetim kurulu üyeleri ve büro personelleri, acenteler ve tur operatörleri, bankalar ve sigorta acenteleri, tanıtım ajansları ve valiliğin destinasyon yönetim sürecinde yer alması gereken paydaşlar olması gerektiğini ifade etmişlerdir. Fakat katılımcıların yerel halkı destinasyon yönetiminde yer alması gereken paydaş olarak belirtmedikleri tespit edilmiştir.

"Antalya kongre bürosunda yerel halktan herhangi bir insan yer almıyor." (K1)"

Destinasyon yönetiminde paydaşların birbirleriyle olan ilişkileri, etkin destinasyon yönetiminin sağlanmasında önemli bir etmendir (İnanır, 2018). Bu süreçte paydaşların birbirleriyle olan ilişkilerinde birden çok etmen rol oynayabilmektedir. 
Antalya Kongre Bürosu'nda destinasyon yönetim sürecinde paydaşlar arası ilişkilerde planlama ve proje geliştirme konusunda kısmen etkinliğinin olduğu ortaya çıkmıştır. Fakat yeteri sayıda proje ortaya konulamaması, paydaşlar arasında motivasyon eksikliğini ortaya çıkardığı bulgusu da elde edilmiştir.

"Antalya Tanıtım Vakfı olarak planlamayı biz sağlıyoruz. Burada planlamada valinin üzerine düssen belediyelerin üzerine düşen veyahut da hava yolunun üzerine düşen eğer bir projemiz var ise o proje bağlamında biz planlama yapıyoruz." (K2).

Bura da daha çok kurul üyeleri arasında yapılan bir planlama. Bizi bir kısım bazen davet edebiliyorlar. (K3).

"Yürütülen proje sayısının az olmasının yarattığı motivasyon eksiklikleri var." (K1).

Antalya Kongre Bürosunun da hem kongre turizmi amaçlı koordineli bir şekilde farklı paydaşlar ile çalışmalar gerçekleştirdiği hem de destinasyon yönetimi amaçlı toplantılar gerçekleştirdiği bulgusu elde edilmiştir. Yapılan toplantılar sayesinde bilgi paylaşımı ve kararlara katılımın da sağlanmaya çalışıldığ 1 görülmektedir. Fakat diğer kurumların özellikle istatistiki boyutta Antalya Kongre Bürosuyla bilgi paylaşımında bulunmadığı bulgusu da ortaya çıkmıştır.

"[...] Bu bağlamda ihtiyaç duyulması halinde Antalya Kongre Bürosu üyelerini ve etkinlik turizminde yer alan üniversiteleri, kongre merkezlerini, belediyeleri, kongre otellerini, profesyonel kongre organizatörlerini ve etkinlik pazarına tedarik hizmeti veren tarafları bir araya getirebilmekte, bahsi geçen taraflarm ulusal ve uluslararası fuarlara katılmalarmm organizasyonuna destek verebilmektedir." (K1).

"Antalya kongre bürosu üyeleriyle ilgili, üyeleri olan kurumlara bilgi veriyor. Bununla ilgili mutlak suretle toplantı yapıyoruz ve toplantılarm sonucunda onları isteklerine göre davranıyoruz." (K2).

"Antalya'da düzenlenen etkinliklerin detaylarmı ve istatistiklerinin Antalya Kongre Bürosu ile paylaşılmasında işletmelerin isteksiz olmaları durumu vardır." (K1)

Destinasyon yönetim örgütleri yönetim sürecinde bir takım problemler ile karşılaşabilmektedir. Nitekim alt yapı ve üst yapı yetersizliği, etkin olmayan reklam ve tanıtım, yetersiz imaj, paydaşların birbirleriyle ilişkilerindeki yetersizlikler (İnanır, 2019) ve yetersiz bütçe (Ersun ve Aslan, 2009) gibi konularda problemler ortaya çıkabilmektedir. Antalya Kongre Bürosu da destinasyon yönetim sürecinde gerek üye sayısındaki yetersizlik gerekse kaynakların etkin bir şekilde dağıtılmamasından dolayı finansal kaynak tahsisi problemi yaşadığı ortaya çıkmıştır. Bu duruma bağlı olarak ofiste çalışan personel sayısında da yetersizlik olduğu ifade edilmiştir.

"Mevcut sorunlar üye sayısının arttırılamaması ve personelinin sayıca az olması." (K1).

"[...] İstanbul kongre bürosu da İstanbul sanayi ve ticaret odasına bağhldır ve bütçesini de oradan yapar. Antalya kongre bürosu da Antalya Ticaret ve Sanayi Odasına bağhlıdır. Başkanı ATSO başkanı fakat İstanbul kadar yoğun destek almıyor." (K2).

"[...] destinasyon yönetimi ile ilgili yeterince kaynağının olmaması, kaynak dağılımı. Kaynak yönetimi gerektirir büyük ölçekle baktı̆̆ımız zaman. Kaynak tamamı ile maddi ve elimizdeki 
şeylerin, satış araçlarının doğru yönlendirilmesi, alınan vergiler buna ayrılan paylar gibi bu tür kaynak yönetimleri." (K3).

Destinasyonların etkin yönetiminin önündeki şüphesiz en önemli engellerden biri de bürokrasidir. (Erkuş-Öztürk, 2011). Özellikle bürokrasinin zayıflatılması, destinasyon yönetim sürecinde işleyişin hızlanması açışından önem arz etmektedir (İnanır, 2019). Bununla birlikte kamu kurumları ile diğer kurumlar arasında ortaya çıkan bürokrasi, destinasyonların şeffaf bir şekilde yönetilmesini olumsuz etkilemektedir. Şeffaflığın olmadığ1 yerde kurumların birbirleri ile etkin iletişimi de sekteye uğramaktadır. Nitekim bu durum ortak karar alma ve amaç birliğinin oluşmaması durumunu ortaya çıkarmaktadır. Benzer gelişmelerin Antalya Kongre Bürosunun destinasyon yönetim sürecindeki işleyişini de olumsuz etkilediği ortaya çıkmıştır.

"Bürokrasi etkenlerden bir tanesi. Bürokrasinin getirdiği hantallı. Diğeri kurumlar arası iletişim. Çünkü gerçekten amacımız bir ama her kurum kendini başarılıymış gibi başarılı işler yapmış gibi düşünüp bunu yeterince piyasayla paylaşmaması diyebilirim. Ya da amaçların ortak olmaması yani farklı bakış açıları. Herkes aynı amaca hizmet ediyor ama bazıları için atıyorum Türkiye'ye bir milyon turist gelmesi $X$ oteli için çok önemli ama örnek veriyorum $Y$ müdürlü̈̆̈̈ için beş yüz gelse de olur." (K3).

"Destinasyon yönetiminde karşılaşmış olduğumuz sorunlar en büyük sorun zannedersen birliktelik. Ortak karar alma birliktelik." (K2).

"Amaçların ortak olmaması, yani farklı bakış açıları." (K4).

\section{Tartışma, Sonuç ve Öneriler}

Dünyada meydana gelen gelişmeler her alanı etkilediği gibi yönetim alanını da etkilemiş, bu durum yönetim alanında bir takım yeni stratejilerin kullanılması gerekliliğini ortaya çıkarmıştır. Bu gelişmeye bağlı olarak turistik destinasyonların etkin bir şekilde yönetilmesinde yönetişim felsefesiyle paydaşların birbirleriyle ilişkilerini geliştirmesi zorunluluğu meydana gelmiştir. Bu zorunluluk ulusal yönetim örgütlerinden, yerel yönetim örgütlerine kadar tüm yönetim örgütlerinde yeterli sayıda paydaşın etkin bir şekilde destinasyon yönetim sürecine dahil edilmesini gerekli kılmıştır. Nitekim bu araştırma destinasyon yönetiminde kongre ve ziyaretçi bürolarının etkinliğini araştırmanın uygulama alanı olan Antalya Kongre Bürosu vasıtasıyla ortaya koymayı amaçlamıştır.

Araştırma sürecinde elde edilen veriler üzerinde yapılan analiz sonuçlarına göre Antalya Kongre Bürosunun hizmet sunduğu destinasyonun satış ve pazarlanması, tanıtılması, kongre turizminin planlanması sürecinde enformasyon sağlanması gibi rol ve sorumluluklarını etkin bir şekilde yerine getirdiği ortaya çıkmıştır. Bu sonuç Antalya Kongre bürosunun yöre turizminin pazarlanması sürecinde gerçekleştirmiş olduğu faaliyet vasıtası ile yörenin ekonomik boyutta kalkınmasına katkı sağlayan bir kuruluş olduğunu ortaya çıkarmıştır.

Antalya Kongre Bürosunun destinasyon yönetiminde özel sektör, sivil toplum kuruluşları ve kamu sektöründen paydaşların yer alması gerektiği sonucu elde edilmiştir. Fakat destinasyon gelişim sürecinde önemli bir yeri olan yerel halkın 
destinasyon yönetiminde yer alması gerektiği ifade edilmemiştir. Delice (2012)'ye göre kongre bürolarının önemli işlevleri kongre yapmaya karar veren, kongreye katılan delegeler ve yerel halk arasında etkin yapıyı sağlayan kuruluşlardır. Özellikle kongreye katılanlar bölgede konaklama, yeme içme tesislerinden yaralandığı gibi kongre sonrası rekreatif etkinliklere de katılmaktadırlar. Nitekim bu süreçte yerel halk ile etkileşim ortaya çıkabilmektedir. Özellikle yerel halkın da sürece dâhil edilmemesi etkin, düzgün ve sürdürülebilir kongre etkinlikleri yapısını olumsuz bir şekilde etkileyebilir.

Antalya Kongre Bürosunun destinasyon yönetim sürecinde planlama ve proje geliştirme sürecinde kısmen etkin olduğu, kongre turizmi amaçlı paydaşlar arası koordinasyonu etkin bir şekilde sağlanmaya çalışıldığı, paydaşlara yapılan toplantılarla bilgiler verildiği, paydaşların sürece dahil edilmeye çalışıldığı sonuçları da elde edilmiştir. Fakat diğer kurum paydaşlarının özellikle istatistiki konularda büroya yeteri bilgi vermediği sonucu ortaya çıkmıştır. Bu durum kongre bürosunun etkin bir şekilde çalışmasını sekteye uğratabilir. Çünkü istatistiki veriler bu gibi kurumların işleyişinde önemli yer tutmaktadır.

Antalya Kongre Bürosunun destinasyon yönetim sürecinde karşılaştığ1 önemli problemlerden ilki üye sayısının yetersiz olmasıdır. Üyeler kongre bürolarının önemli birer finansal kaynağıdır. Bu durumun ortaya çıkması Antalya Kongre Bürosunun da finansal olarak problem yaşaması durumunu ortaya çıkarmıştır. Diğer bir finansal sorun ise finansal kaynakların etkin bir şekilde yönetilememesidir. Burada kurum için ayrılan finansal kaynağın yetersiz olması durumu, gerek büronun personel sayısını gerekse destinasyon yönetim sürecindeki etkinliğini olumsuz bir şekilde etkileyebilmektedir. Antalya kongre bürosunun destinasyon yönetim sürecinde karşılaşmış olduğu diğer önemli bir problem ise bürokratik engellerdir. Kamu sektörü ile özel sektör ve sivil toplum kuruluşları arasında ortaya çıkan bürokratik engeller destinasyonların etkin bir şekilde yönetimi de olumsuz bir şekilde etkileyebilmektedir. Diğer bir ifadeyle destinasyon yönetim sürecinde kurumların birbirleri ile ilişkilerinde ortaya çıkan zayıflık, kurumlar arası etkin iletişiminin sağlamaması, ortak karar alamama ve vizyon birliğinin oluşamaması gibi problemleri beraberinde getirmektedir. Bu durum da destinasyonların etkin rekabet edememesi gibi birçok problemi ortaya çıkarmaktadır.

Genel olarak değerlendirildiğinde Antalya Kongre Bürosunun kongre turizmi amaçlı satış pazarlama, tanıtım ve planlama konusunda etkin olduğu fakat destinasyon yönetim sürecini sağlamaya çalışırken bir takım problemlerle karşılaştığı sonuçları ortaya çıkmıştır. Bu doğrultuda Antalya Kongre Bürosunun destinasyon yönetim sürecinde etkinliğinin artırılabilmesi adına bir takım önerilerde bulunulabilir. Bu bağlamda ilk olarak tek elden ve daha güçlü bütçeyle tanıtım, pazarlama, eğitim ve araştırma faaliyetleri organize edilebilir. Ayrıca yurtdışında olduğu üzere vergilerden sabit yüzdeler kongre ve ziyaretçi bürolarının faaliyetleri için ayrılabilir. Diğer bir ifadeyle kongre ve ziyaretçi bürolarının etkin faaliyetlerini sürdürebilmeleri adına finansal kaynak tahsis sorunlarının çözüme kavuşturulması için üye sayısının arttırılmasının yanında farklı kaynaklar da tahsis edilebilir. Aynı zamanda mevcut haliyle tüm kongre ve ziyaretçi bürolarının ayakta kalabilmeleri için illerin Ticaret ve Sanayi Odalarına konuyla ilgili kuruluşlar tarafından destekler sağlanabilir. Bu konuda Çizel'in (1999) belirtildiği gibi kongre ve ziyaretçi bürolarının gelirlerinde kamunun 
etkisi oldukça fazladır. Bu nedenle valilik önderliğinde belediyeler ve il özel idareleri gibi kamu paydaşlarının sağlayabileceği bütçe ile de finansal kaynak tahsisi ve bu sayede personel sayısındaki yetersizlik problemi gibi birçok problem ortadan kaldırılabilir.

İkinci olarak Türkiye etkinlikler ülkesi olduğu için yurtdışında daha iyi tanıtım materyali ve daha yüksek bütçeler kullanılarak anlatılması gerekmektedir. Bu konuyla ilgili de gerekli desteklerin Antalya Kongre Bürosuna verilmesi gerekmektedir. Bu sayede özellikle faaliyete katıldığı zaman diliminde, günübirlik turizm türlerine oldukça fazla harcama yapan kongre turistlerinin bölgeye olan katkısı da arttırılabilir. Bu durum bölgenin ekonomik olarak kalkınmasını da arttırabilecektir.

Üçüncü olarak destinasyon yönetiminin gelişiminde etkin olan yerel halk ile Antalya Kongre Bürosunun aralarındaki ilişkilerin arttırılmasına yönelik çalışmalar gerçekleştirilebilir. Özellikle 2023 Türkiye Turizm Stratejilerinde de belirtildiği gibi tanıtma, planlama ve uygulama konularında (Kültür ve turizm Bakanlığı, 2007) ilgili kuruluşların aktörleri ile Antalya Kongre Bürosu aktörleri arasında yapılan projelerin yanında daha da etkin projeler geliştirilebilir. Bununla birlikte kurumlar arası bürokrasinin de azaltılması işleyişi de kolaylaştıracaktır.

Son olarak araştırma sürecinde gerek zaman, gerekse Covid-19 salgınından dolayı birtakım kısıtlılıklar ortaya çıkmıştır. Bu nedenle araştırma sadece Antalya Kongre Bürosu ve 4 katılımcı ile sınırlı tutulmuştur. Gelecekte araştırmacılar İstanbul ve Ankara gibi kongre bürolarını ve farklı türde paydaşları da sürece dâhil ederek daha geniş çaplı araştırmalar ortaya koyabilirler. Bunun yanında bu bürolar ile Antalya Kongre Bürosu arasında karşılaştırmalı araştırmalar gerçekleştirebilirler.

\section{Kaynakça}

Baltacı, A. (2019). Nitel araştırma süreci: Nitel bir araştırma nasıl yapılır? Ahi Evran Üniversitesi Sosyal Bilimler Enstitüsü Dergisi, 5(2), 368-388.

Baytok, A., Soybalı, H. H. ve Emir, O. (2010). Destinasyonların toplantı turizmi amaçlı pazarlanmasında kongre ve ziyaretçi bürolarının rolü: İstanbul Kongre ve Ziyaretçi Bürosu Örneği. Selçuk Üniversitesi Sosyal Bilimler Enstitüsü Dergisi, 23, 9-22.

Beldona, S., Morrison, A. M. ve Anderson, D. J. (2003). Information exchange between convention and visitor bureaus and hotels in destination marketing. Journal of Convention $\mathcal{E}$ Exhibition Management, 5(1), 41-56.

Berg, B. L. ve Lune, H. (2016). Sosyal bilimlerde nitel araştırma yöntemleri. Eğitim Yayınevi.

Borzyszkowski, J. (2014). Destination management organizations and sports events. International Journal of Tourism Sciences. 14(2), 170-198.

Bramwell, B. ve Rawding, L. (1994). Tourism marketing organizations in industrial cities: organizations, objectives and urban governance. Tourism Management, 15(6), 425-430.

Buhalis, D. (2000). Marketing the competitive destination of the future. Tourism Management, 21(1), 97-116.

Creswell, J. W. (2012). Educational research: planning, conducting, and evaluating quantitative and qualitative research. Pearson Education.

Creswell, J. W. (2016). Nitel araştırma yöntemleri beş yaklaşıma göre nitel araştırma ve araştırma deseni. Siyasal Kitabevi.

Çakar, K., Kalbaska, N., İnanır, A. ve Şahin Ören, T. (2018). eVisa's impact on travel and tourism: the case of Turkey. Journal of Hospitality and Tourism Tecnology. 9 (1), 13-31. 
Çizel, B. (1999). Kongre Turizmi, Kongre Organizasyonu ve Antalya Bölgesinin Kongre Turizm Potansiyeli, Sorunları ve Gelecekteki Beklentilere Yönelik Bir Araştırma [Yayımlanmamış Yüksek Lisans Tezi]. Akdeniz Üniversitesi.

Delice, K. (2012). Kongre Turizm ve Türkiye'deki Toplantılarda Katılımo Algılarının İncelenmesi; Antalya Yöresinde Bir Uygulama [Yayımlanmamış Yüksek Lisans Tezi]. Akdeniz Üniversitesi.

Erkuş-Öztürk, H. (2011). Modes of tourism governance: a comparison of amsterdam and antalya. Anatolia: An International Journal of Tourism and Hospitality Research, 22(3), 307-325.

Ersun, N. ve Aslan, K. (2009). Kongre turizminin geliştirilmesinde kongre ve ziyaretçi bürolarının rolü ve önemi. İstanbul Ticaret Üniversitesi Sosyal Bilimler Dergisi, 8(15), 89-114.

Gartrell, R. B. (1994). Destination marketing for convention and visitor bureaux. Kendal/Hunt.

Gartrell, R.B. (1993). Convention and visitor bureaus: current issues in management and marketing. Journal of Travel and Tourism Marketing, 1(2), 71-78.

Getz, D., Anderson, D. ve Sheehan, L. (1998). Roles, isues, and strategies for convention and visitors' bureaux in destination planing and product development: A Survey of Canadian bureaux. Tourism Management, 19(4), 331-340.

Graham, J., Amos, B. ve Plumptre, T. (2003). Principles for Good Governance in The $21^{\text {st }}$ Century. Policy Brief.

Gray, J. H. ve Densten, I. L. (1998). Integrating quantitative and qualitative analysis using latent and manifest variables. Quality \& Quantity, 32, 419-431.

Güripek, E. ve Usta, Ö. (2018). Turizm Destinasyonlarının Rekabet Gücünün Artırılmasında Stratejik Destinasyon Yönetimi: Çeşme Alaçatı Destinasyonu Üzerine Bir Uygulama. Journal of Tourism and Gastronomy Studies, 6(4), 496-523.

Ha, M. ve Love, C. (2005). Exploring content and design factors associated with convention and visitors bureau web site development. Journal of Convention \& Event Tourism, 7(1), 4359.

Hu, Y. ve Ritchie, J. R. B. (1993). Measurung destination attractiveness: a contextual approach. Journal of Travel Research, 32(3), 25-34.

İnanır, A. (2018). Destinasyon Yönetimi Kapsamında Paydaşlar Arası İlişkiler Üzerine Bir Araştırma: Göller Yöresi Örneği [Yayınlanmamış Doktora Tezi]. Akdeniz Üniversitesi.

İnanır, A. (2019). Turistik destinasyon yönetiminde paydaşlar arası ilişkiler: Göller Yöresi Örneği. Türk Turizm Araştırmalar Dergisi, 3(3), 517-541.

Kotler, P., Bowen, J. T. ve Makens, C. (2006). Marketing for hospitality and tourism. Pearson Prentice Hall.

Kovacevic, I. (2017). Convention bureau perspectives on destination management: 1dentification and classification of activities. Ekonomika Preduzeca, DOI: 10.5937/EKOPRE1704259K.

Kültür ve Turizm Bakanlığı. (2007). Türkiye Turizm Stratejisi (2023). Kültür ve Turizm Bakanlığı.

Leiper, N. (1995). Tourism management. RMIT.

Marshall, M. N. (1996). Sampling for qualitative research. Family Practice, 13(6), 522-526.

Morrison, A.M., Bruen, S.M. ve Anderson, D.J. (1998). Convention and visitor bureaus in the USA: a profile of bureaus, bureau executives, and budgets. Journal of Travel and Tourism Marketing, 7(1), 1-19.

Murphy, P. E. ve Murphy, A. E. (2004). Strategic management for tourism communities. View Publications.

O'neill, J. W. (1998). Effective municipal tourism and convention operations and marketing strategies: the cases of Boston, San Antonio and San Francisco. Journal of Travel \& Tourism Marketing, 7(3), 95-124.

Pearce, D. (1992). Tourist organizations. Longman Group UK Ltd. 
Pearce, D. G. ve Schanzel, H. A. (2013). Destination management: the tourists' perspective. Journal of Destination Marketing and Management, 2, 137-145.

Penclaner, H. ve Weiermaier, K. (2000). Destination management: fondementi di marketing e gestione delle destinazioni turistiche. Touring Editore.

Presenza, A., Sheehan, L. ve Ritchie, J. R. B. (2005). Towards a model of the roles and activities of destination management organizations. Journal Of Hospitality, Tourism $\mathcal{E}$ Leisure Science 3, 1-16.

Ritchie, J. R. B., ve Crouch, G. I. (2003). The competitive destination: a sustainable tourism perspective. CABI Publishing.

Seale, C. (1999). Quality in qualitative research. Oualitative Inquiry, 5(4), 465-478.

Speakman, M. ve Sharpley, R. (2012). A chaos theory perspective on destination crisis management. Journal of Destination Marketing and Management, 1(1-2), 67-77.

Starks, H. ve Trinidad, S. B. (2007). "Choose Your Method: A Comparison of Phenomenology, Discourse Analysis, and Grounded Theory", Qualitative Health Research, 17(10), 13721380.

Tinsley, R. ve Lynch, P. (2001). Small tourism business networks and destination development. International Hospitality Management, 20(4), 367-378.

Wang, Y. (2011). Destination Marketing systems: critical factors for functional design and management. In Y, Wang ve A, Pizam (Eds.), Destination marketing and management theories and applications. (s. 184-204) USA: CAB International.

Weber, K. (2001). Meeting Planners Use and Evaluation of Convention and Bureaus. Tourism Management, 22, 599-606.

Wober, K.W. (2003). Information supply in tourism management by marketing decision support systems. Tourism Management, 24, 241-255.

World Tourism Organization. (2004). Destination management organisations report. Madrid: World Tourism Organization.

Yirik, Ş., Seyitoğlu, F. ve Çakar, K. (2016). From the White Darkness to Dark Tourism: The Case of Sarikamish. International Journal of Culture, Tourism and Hospitality Research. 10(3), 245-260. 